
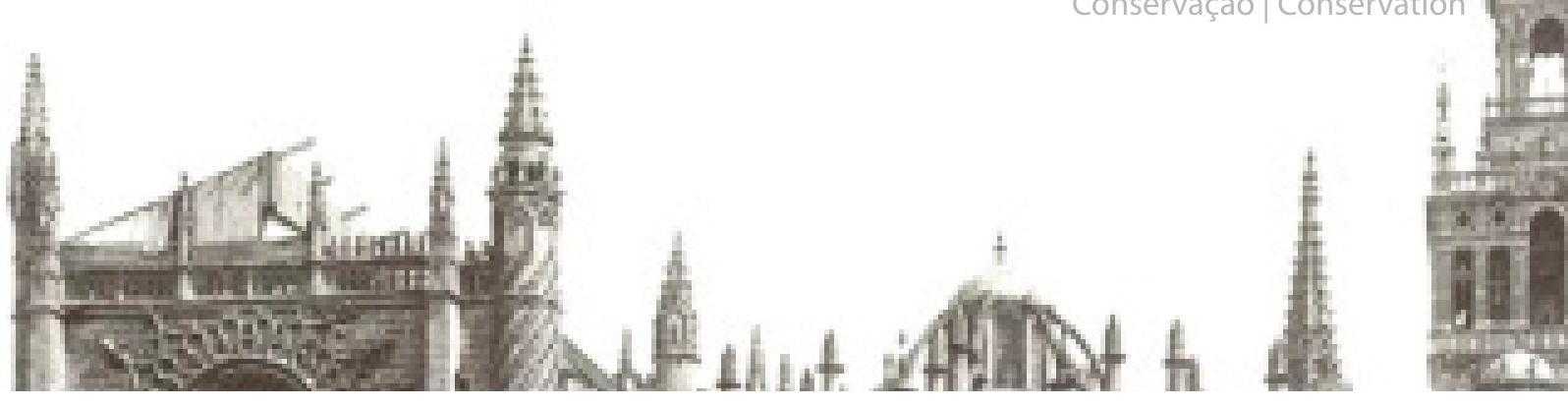

\title{
The performance of shelters for the conservation of archaeological sites in dry and warm climates: the case of Complutum
}

\author{
Cristina Cabello Briones
}

\begin{abstract}
Excavated archaeological sites are frequently exposed to damaging environmental conditions, which could lead to rapid decay especially for vulnerable heritage such as mosaics. One of the most common solutions is the construction of shelters; however, some may not behave as expected, either because they do not protect adequately or induce decay. An environmental monitoring programme was undertaken inside and outside the two types of shelters at the Roman archaeological site of Complutum (Alcala de Henares, Spain) from May to September in 2018 and 2019. Hourly temperature and relative humidity readings collected by data loggers, together with rainfall data from a local meteorological station, have been comparatively assessed to better understand the consequences of sheltering in dry and warm areas. The results indicate that both shelters are avoiding further decay by keeping a more stable environment in relation to outside, although the more enclosed structure would be the most suitable one.
\end{abstract}

Keywords: Preventive conservation, built heritage, archaeological remains, covers, environmental monitoring, temperature, relative humidity

\section{El comportamiento de las cubiertas para la conservación de yacimientos arqueológicos en climas secos y cálidos: el caso de Complutum}

Resumen: Los yacimientos arqueológicos excavados se exponen frecuentemente a condiciones ambientales dañinas, que pueden llevar a un rápido deterioro especialmente en el patrimonio vulnerable como los mosaicos. Una de las soluciones más comunes es la construcción de cubiertas; sin embargo, algunas pueden no comportarse como se esperaba, bien porque no protegen adecuadamente bien provocan daño. Se ha realizado un programa de monitoreo ambiental dentro y fuera de los dos tipos de cubiertas del yacimiento arqueológico romano de Complutum (Alcalá de Henares, España) desde Mayo a Septiembre del 2018 y 2019. Las lecturas de temperatura y humedad relativa recogidas cada hora por data loggers, junto con los datos de precipitación de una estación meteorológica local, se han evaluado comparativamente para entender mejor las consecuencias de cubrir en áreas secas y cálidas. Los resultados indican que ambas cubiertas están evitando futuro deterioro al mantener un ambiente más estable en relación con el exterior, aunque la estructura más cerrada sería la más adecuada.

Palabras clave: Conservación preventiva, patrimonio construido, restos arqueológicos, cubiertas, monitoreo ambiental, temperatura, humedad relativa

\section{Introduction}

Archaeological excavations imply uncovering the remains; therefore, affect the conservation of both delicate features and archaeological sections (Barrio Martín 2012). Shelters have been largely used as preservation strategies for exposed archaeological sites because, as opposed to other sys-tems such as backfilling, provide with protection and the possibility of still visiting the site during ongoing excavations (Roby 2006). Their main purpose is to act as barriers (Doehne and Price 2010), thus avoiding the rain and reducing, consequently, the moisture content in porous inorganic materials, which primarily composed the archaeological remains that are left in situ. Shelters can also stabilize the environmental conditions for long-term conservation; however, if not properly built, they may not provide protection or even induce decay on the remains by, for example, modifying microclimatic parameters and favouring salt crystallization or biocolonisation (Aslan 1997; Cabello Briones 2018). In those situations, improvements should be made, and the possibility of dismantling the shelters considered (Curteis 2018). The evaluation of existing covers must take place regularly to corroborate their protective function and the 
presentation of results from individual cases, which in general is still very limited, offers significant contributions to current discussions, such as the suitability of the shelter design (Pesaresi and Stewart 2018).

Complutum (40 28' 26.146" N, $3^{\circ} 23^{\prime} 16.49^{\prime \prime} \mathrm{W}$ ) is a Roman archaeological site part of the historic precinct of the modern city of Alcala de Henares (Comunidad de Madrid, Spain) [figure 1]. The site, which main construction materials are rammed earth, masonry and brick, is decorated with mural paintings and mosaics. Complutum was declared of cultural interest under the Spanish legislation in 1992, which implies the maximum protection, and included in the UNESCO World Heritage list in 1999. Alcalá de Henares, located in the centre of the Iberian Peninsula, is defined as a cold semi-arid climate (BSk) according to the Köppen-Geiger classification. This area is characterised by relatively wet winters, but mainly hot and dry summers. This is important as the climatic location of a site conditions the decay mechanisms (Cabello Briones and Viles 2017).

Currently, there are two areas of the site covered with shelters: the House of Hippolytus and the House of the
Griffins [figure 2]. A summary of the construction details is presented in table 1. The House of Hippolytus is a more enclosed structure while the other one, built later in time, is in line with the worldwide tendency of building shelters without lateral claddings (Cabello Briones 2016). A major difference between enclosed and open shelters is that the second ones are usually lighter structures that avoid deep foundations and the subsequent possibility of decay for the unexcavated archaeological remains.

At the start of the study, the conservation state of the ruins inside the shelters at Complutum was identified as stable by visual surveying [figure 3]. This could be related to the regular maintenance carried out by the Archaeological Service in charge of the site since the construction of the shelters. This includes, among other actions, a monthly cleaning of surfaces, and the application of biocides (octyl- isotiazol and aluminium salts) and consolidates (ethyl silicate) at least once per year (Argea Consultores 2017). Conversely, there are relevant signs of long-term and recent decay outside the shelters, mainly in the form of physical and biological deterioration, which indicate that these types of weathering would also affect the covered areas if left exposed.
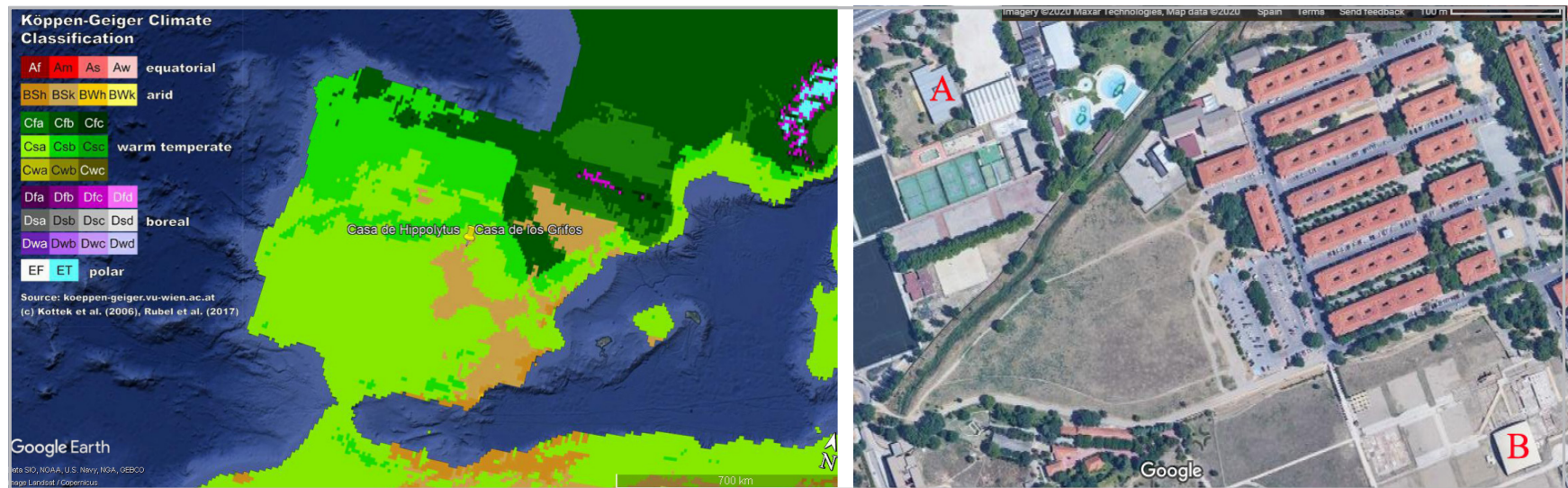

Figure 1.- Geographical location of the site with the Köppen climate classification (left), and an aerial view of the House of Hippolytus (A) and the House of the Griffins (B) (right)
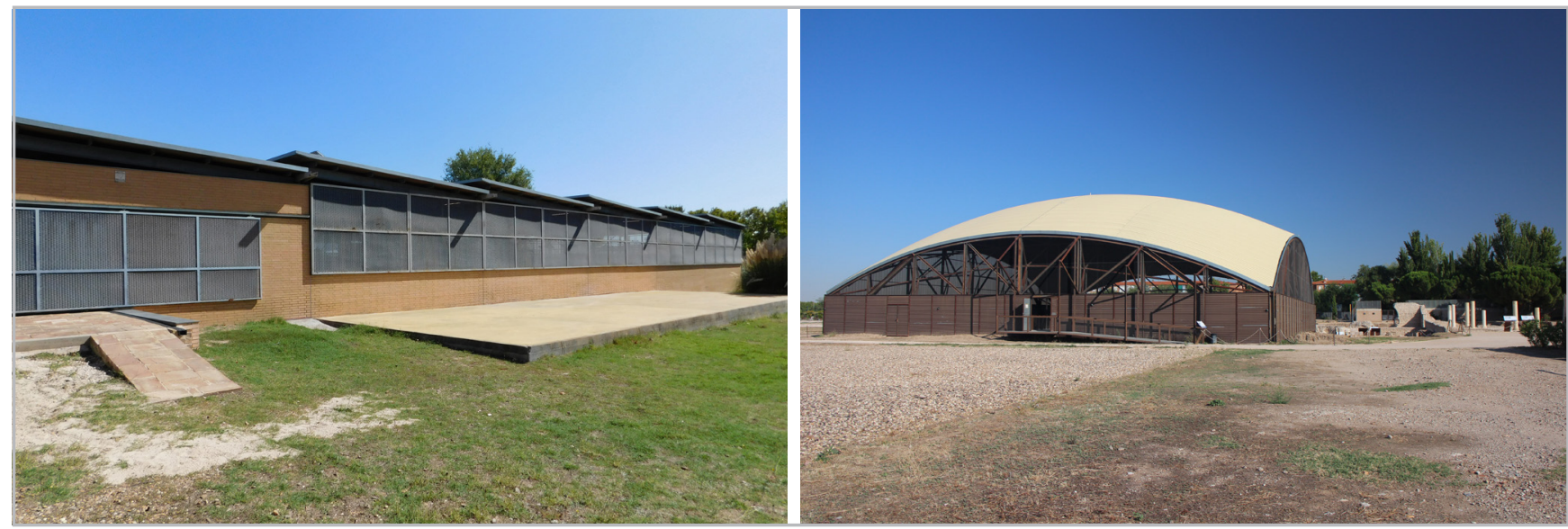

Figure 2.- The shelters at the House of Hippolytus (left) and the House of the Griffins (right) viewed from outside (Photos: C. Cabello Briones) 
Table 1.- Comparative between the House of Hippolytus and the House of the Griffins in terms of construction characteristics

\begin{tabular}{|l|l|l|}
\hline & House of Hippolytus & House of the Griffins \\
\hline Year of construction & 1999 & 2011 \\
\hline Covering area & $1318 \mathrm{~m} 2$ approx. & $1300 \mathrm{~m} 2$ approx. \\
\hline Type of shelter & Partially enclosed shelter & Semi open shelter \\
\hline Description & $\begin{array}{l}\text { Enclosure with strip footings and load bearing } \\
\text { walls }\end{array}$ & $\begin{array}{l}\text { Dome-shape steel structure with reduced lateral } \\
\text { cladding }\end{array}$ \\
\hline Construction materials & $\begin{array}{l}\text { Cover: galvanized steel sheets in the outer part } \\
\text { and hydrophobic agglomerate wooden boards in } \\
\text { the inner part. } \\
\text { Walls: galvanised expanded metal meshes in the } \\
\text { upper part and bricks in the lower part. }\end{array}$ & $\begin{array}{l}\text { Cover: sandwich system of pre-coated steel sheets } \\
\text { and } 90 \text { mm fiberglass panels. } \\
\text { touching the floor): galvanised expanded metal } \\
\text { meshes in the upper part and } 1 \text { mm galvanized corru- } \\
\text { gated sheets. }\end{array}$ \\
\hline Architects & $\begin{array}{l}\text { Juan Pablo Rodríguez Frade } \\
\text { References }\end{array}$ & $\begin{array}{l}\text { Rodríguez Frade 2001 } \\
\text { Pablo Latorre González-Moro and Leandro Cámara } \\
\text { Muñoz }\end{array}$ \\
\hline
\end{tabular}
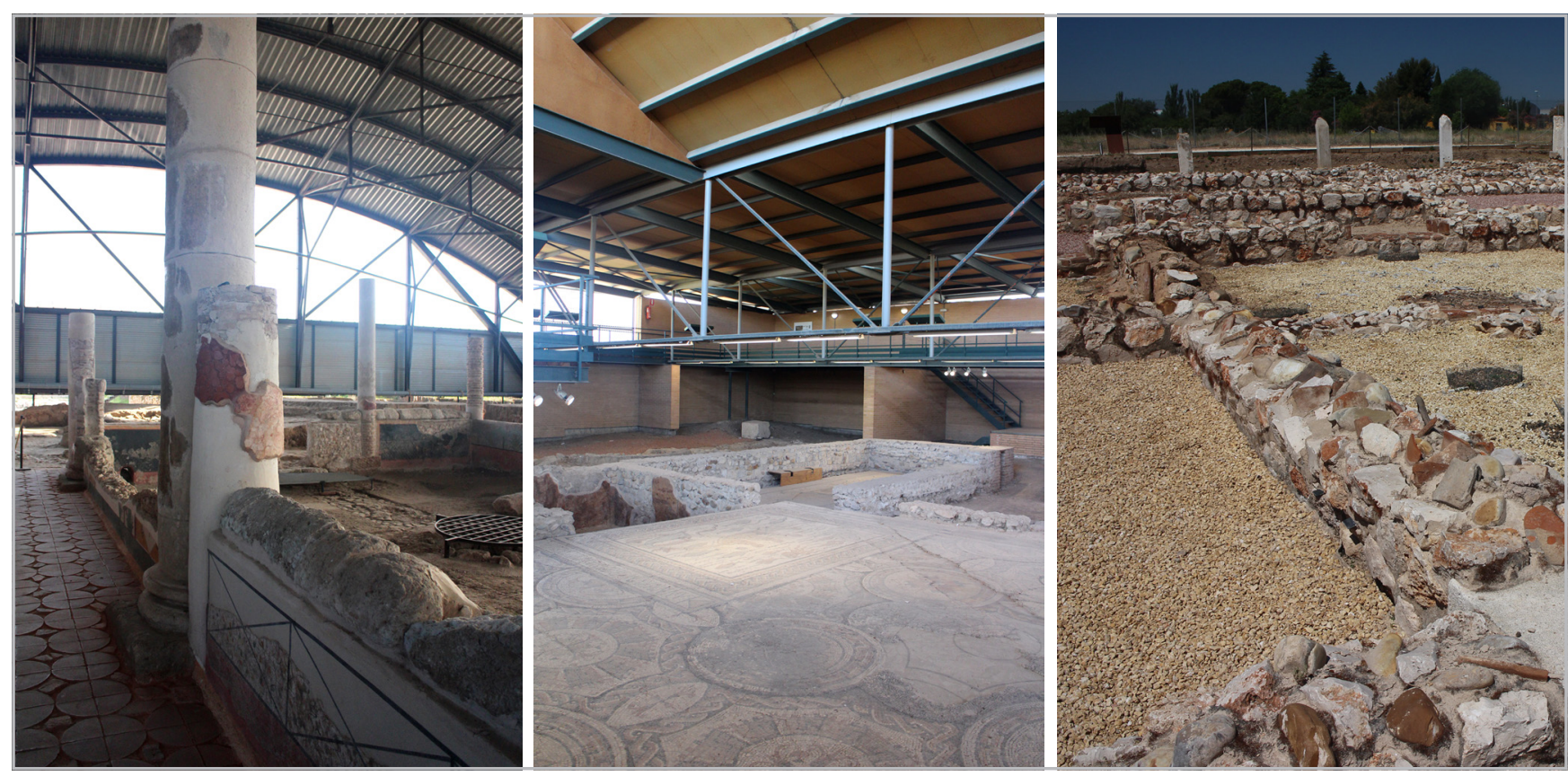

Figure 3.- View from inside of the House of Hippolytus (left) and the House of the Griffins (middle), and a detail of the remains located at the House of Mars (right), exposed without covering (Photos: C. Cabello Briones)

It is generally agreed that visual surveys are necessary in order to have an initial understanding of the possible problems affecting a site but the complexity related to the great variety of materials, restoration treatments and condition states of the remains makes them unreliable for an objective comparison. Therefore, in-depth evaluation of the shelters should also imply a monitoring programme over a representative period of time (Pesaresi and Stewart 2018).
Most of the environmental assessments on shelters have studied temperature and relative humidity $(\mathrm{RH})$ (Demas 2013). These variables are involved in wetting and drying events, salt crystallization, biological attack, and hygric and thermal expansion and contraction of building materials and structures (Torraca 2009), which are the mechanisms highly responsible for the decay at exposed archaeological sites (Curteis 2018). 
A temperature and $\mathrm{RH}$ monitoring, together with a study on rainfall, is especially useful for dry and warm climates, characterised by intense solar radiation, which in the case of central Spain can reach a mean daily of $16 \mathrm{MJ} / \mathrm{m}^{2}$, and sometimes short but intense rain spells (De Castro et al. 2005). Building materials under solar radiation absorb energy during the day, which result in expansion, while at night, contract and release infrared radiation. Thermal cycles, which include both diurnal and seasonal, cause stresses due to the repetitive changes of dimensions, especially in materials with anisotropic thermal behaviours or with different thermal expansion coefficients (Torraca 2009). In addition, high surface temperatures result in a faster drying, which reduces the risk for biocolonisation but favours the crystallization of salts already present in the ruins. Therefore, frequent wet/dry cycling lead to differential stresses, which could induce cracking, detachment or flaking (Doehne and Price 2010).

An environmental assessment primarily based on temperature and relative humidity readings outside and inside the shelters at Complutum has been undertaken during two consecutive years. The data from the warmest months have been comparatively assessed to determine if the shelters are providing adequate conditions for the preservation of the archaeological remains. The results will help to better understand the consequences of sheltering in dry and warm areas, and establish which type of shelter could be the most suitable option in that case.

\section{Research methods}

This study presents the results of an environmental monitoring programme of four months per year (from $17^{\text {th }}$ May to $17^{\text {th }}$ September) in 2018 and 2019. The research was undertaking using small data loggers (Lascar Electronics, accuracy $\left.=0.55{ }^{\circ} \mathrm{C}, 2.25 \% \mathrm{RH}\right)$, synchronised to provide with hourly air temperature and $\mathrm{RH}$ values, and based on the method used by Cabello Briones (2017). Inside the two shelters, the loggers were placed just under the centre of the cover to obtain representative data of the most protected areas. They were deposited on the top of site columns to avoid losing information by vandalism or perturbing the visitors of the site, which remained open during the monitoring time. Another logger was located outside the House of the Griffins also over a pillar, but in this case, this corresponds to a reconstructed vertical section of the site. For information about precipitation and climatic trends in the area, data was provided by a nearby meteorological station (Red de Calidad del Aire de la Comunidad de Madrid, CAM code 28005002).

Non-parametric Mann-Whitney-Wilcoxon tests were undertaken to compare daily means and standards deviations of temperature and $\mathrm{RH}$. This allowed determining if there were statically significant differences among the studied locations.

\section{Results}

\section{-Temperature}

Alcalá de Henares is included in the cold semi-arid regime [figure 1], which implies that annual mean temperatures are below $18^{\circ} \mathrm{C}$. In 2018 , the mean temperature was 14.63 ${ }^{\circ} \mathrm{C}$, slightly lower than the next year, $15.22^{\circ} \mathrm{C}$. However, temperatures from just the monitoring period [table 2] keep this site closer to the Mediterranean climate (Csa classification), characterised by extremely dry summers and mean temperatures in the hottest months above 22 ○C (Agencia Estatal de Meteorología 2011).

The hottest months corresponded to August 2018 (max T outside $=41.50^{\circ} \mathrm{C}$ ) and July 2019 ( $\max$ T outside $=43$

Table 2.- Mean temperatures and standard deviations $\left({ }^{\circ} \mathrm{C}\right)$ outside, and inside the shelters at the House of the Griffins and Hippolytus from May to September 2018 and 2019

\begin{tabular}{|c|c|c|c|c|c|c|}
\hline & 2018 & & & 2019 \\
\hline & $\begin{array}{c}\text { House of the } \\
\text { Griffins }\end{array}$ & Outside & $\begin{array}{c}\text { House of } \\
\text { Hippolytus }\end{array}$ & $\begin{array}{c}\text { House of the } \\
\text { Griffins }\end{array}$ & $\begin{array}{c}\text { Outside } \\
\text { House of } \\
\text { Hippolytus }\end{array}$ \\
\hline May & $18.39(3.24)$ & $18.73(4.16)$ & $17.96(2.79)$ & $19.36(4.80)$ & $19.94(4.82)$ & $19.04(4.23)$ \\
\hline June & $22.49(5.76)$ & $22.83(6.31)$ & $22.01(5.41)$ & $24.55(5.72)$ & $25.22(7.66)$ & $24.28(5.26)$ \\
\hline July & $26.53(4.21)$ & $26.65(4.47)$ & $25.98(3.71)$ & $28.59(4.48)$ & $29.60(4.96)$ & $28.32(3.95)$ \\
\hline August & $27.81(4.54)$ & $28.70(4.93)$ & $27.18(3.98)$ & $26.56(4.61)$ & $27.46(4.61)$ & $26.28(4.11)$ \\
\hline September & $24.48(4.00)$ & $26.57(6.12)$ & $23.72(3.21)$ & $25.26(4.27)$ & $27.54(5.01)$ & $24.82(3.50)$ \\
\hline
\end{tabular}


$\left.{ }^{\circ} \mathrm{C}\right)$. The number of times the outer temperature exceed $35^{\circ} \mathrm{C}$ during those months was 65 in August (8.74\% of total readings for this month) and 119 in July (15.19\%). However, high temperatures were also very frequently recorded inside the House of the Griffins: 43 for August 2018 (5.78\%) and 55 for July 2019 (7.39\%). While the number was considerably reduced inside the House of Hippolytus: 21 (2.82\%) and 28 (3.76\%) for those months.

Statistical tests on daily mean temperatures certified that temperature outside was significantly warmer than inside both shelters in 2018 and 2019. On the other hand, higher mean temperatures were recorded systematically inside the House of the Griffins in comparison with the other cover $\left(U=7750\right.$, p-value $<2.2 e^{-16}$ for 2018 , and $U=5379.5$, $p$-value $=8.2 \mathrm{e}^{-14}$ for 2019).

In addition to extreme temperature values, another key element in the decay of archaeological sites is the extent of the diurnal differences between maximum and minimum temperatures [table 3], which are associated with solar heating and night cooling events. The greatest diurnal variances were recorded outside, but if both shelters are compared, the data obtained from the House of Hippolytus indicate that this shelter is performing more efficiently, minimising the temperature range.

These differences are clearly seen in the representation of the hourly means of temperature in August 2018 and July 2019, which were the warmest months of the monitoring period [figure 4]. These graphs also show when the minimum and maximum temperatures are reached. From sunrise (at 7:25 in average in August and 6:57 in July), temperatures increase steadily mainly outside of the shelters. On the contrary, the covers avoid direct sunlight on the ruins and keep the inner temperatures lower in relation to outside. However, after sunset (at around 21:42 in August and 21:10 in July), temperatures inside both shelters are slightly higher than outside, revealing a reduced greenhouse effect. The shelters probably limit the transmission to the sky of the IR radiation emitted to the ruins by night, and cause an increase in the temperature inside (Torraca 2009).

Table 3.- Monthly means and standard deviations $\left({ }^{\circ} \mathrm{C}\right)$ of the daily temperature differences (Tmax-Tmin) outside, and inside the shelters at the House of the Griffins and Hippolytus from May to September 2018 and 2019

\begin{tabular}{|c|c|c|c|c|c|c|}
\hline & & 2018 & & & 2019 & \\
\hline & $\begin{array}{c}\text { House of the } \\
\text { Griffins }\end{array}$ & Outside & $\begin{array}{l}\text { House of } \\
\text { Hippolytus }\end{array}$ & $\begin{array}{c}\text { House of the } \\
\text { Griffins }\end{array}$ & Outside & $\begin{array}{l}\text { House of } \\
\text { Hippolytus }\end{array}$ \\
\hline May & $8.43(2.33)$ & $10.87(2.41)$ & $6.77(1.87)$ & $11.57(3.71)$ & $11.60(3.22)$ & $9.50(2.90)$ \\
\hline June & $10.22(2.99)$ & $11.55(2.35)$ & $8.37(2.51)$ & $11.60(2.77)$ & $14.43(7.89)$ & 9.42 (1.87) \\
\hline July & $12.08(1.94)$ & $12.35(1.76)$ & $9.92(1.54)$ & $12.24(2.41)$ & $15.71(6.54)$ & $9.98(2.22)$ \\
\hline August & $12.98(1.80)$ & $13.47(2.00)$ & $10.00(1.47)$ & $13.11(3.07)$ & $13.10(3.35)$ & $10.21(1.86)$ \\
\hline September & $12.00(2.73)$ & $15.68(5.91)$ & $7.62(1.53)$ & $12.75(3.66)$ & $15.63(3.71)$ & 9.63 (1.93) \\
\hline
\end{tabular}

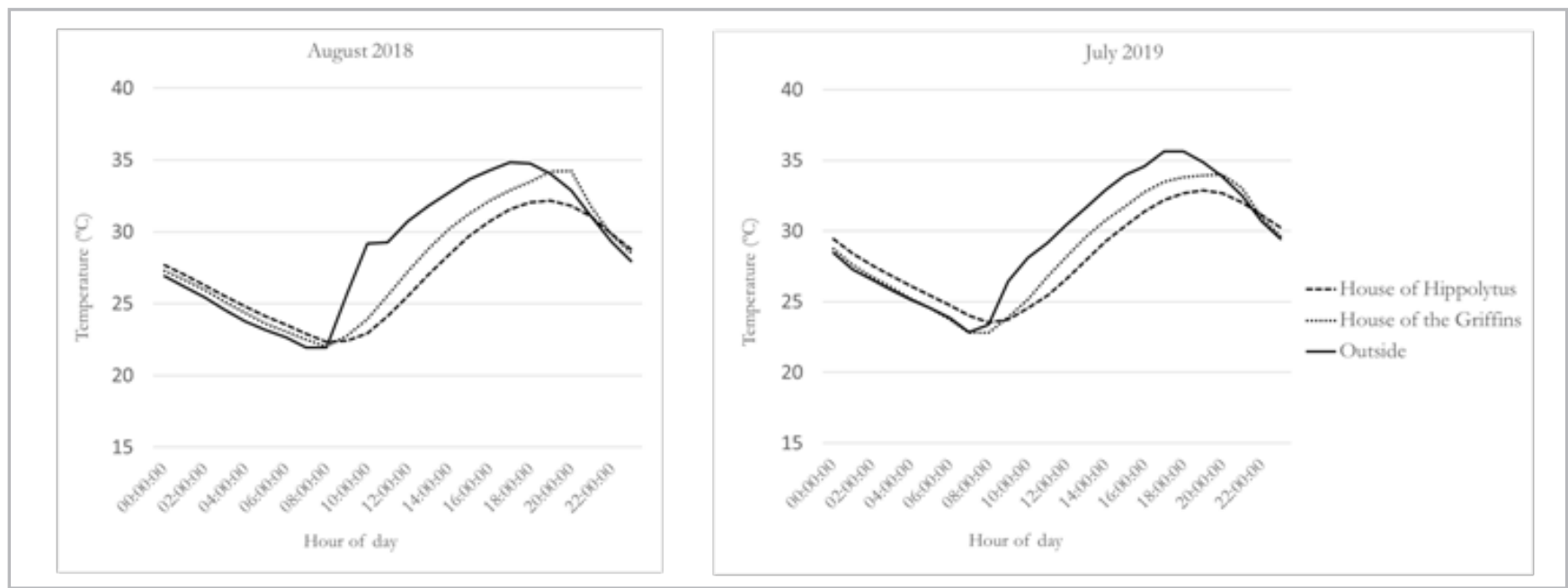

Figure 4.- Hourly means of temperature outside, and inside the shelters at the House of the Griffins and Hippolytus in August 2018 and June 2019, which corresponds to the hottest months of the monitoring programme 
The thermal lag between the outdoor and indoor environment during this period was of around 3 hours if maximum temperatures are compared. The temperature peak in August 2018 and July 2019 was recorded at around 17:00 outside and 20:00 inside the shelters [figure 4], without great difference between the covers in this aspect. Together with the expected thermal inertia of the architectural remains, which time-shift and flatten out temperature fluctuations, there is a surprising increase in temperature inside the House of the Griffins around 20:00, which is associated with sunlight coming in from the west side and reaching the ruins under the central part of the shelter. Therefore, the more open structure of this shelter increases the risk of decay for the mural paintings located in that area, vulnerable to sudden heating and ultraviolet radiation (Camuffo 2019).

Additionally, the data concerning the House of the Griffins complement the one obtained by Martínez Garrido et al. (2016) between December 2014 and July 2015. In that study, it was re-corded a daily thermal lag of approximately 5 hours. More specifically, during the warmest months, the highest outdoor temperature was documented at 13:00 and the inner one at 19:00.

\section{_-Precipitation and Relative Humidity}

The total rainfall in Alcala de Henares from May 2018 to 2019 was $398.60 \mathrm{~mm}$, which confirms that this is a region with a low precipitation rate. In addition, the $70 \%$ of the annual precipitation was collected in autumn and winter, so this area can be also classified by its dry summers (Agencia Estatal de Meteorología 2011). Specifically, between May and September 2018, it was recorded $134.50 \mathrm{~mm}$, and $100.20 \mathrm{~mm}$ during the same period in 2019. The maximum values of daily rainfall, $17.80 \mathrm{~mm}$ and $32.20 \mathrm{~mm}$ respectively, were logged at the end of the summer (12 $2^{\text {th }}$ September 2018 and $15^{\text {th }}$ September 2019).
During the second case, $21.4 \mathrm{l} / \mathrm{m}^{2}$ were just collected in an hour (from 13:00 to 14:00) which indicates that around $20 \%$ of the total rainfall could concentrate in heavy events.

On the other hand, the mean RH in Alcalá de Henares was $46.16 \%$ in 2018 , while $37.46 \%$ in the following year. Inside the shelters, $\mathrm{RH}$ values during the monitoring period were also low (below 65\%), mainly in 2019 [table 4], following the annual trend.

Statistical tests on daily mean $\mathrm{RH}$ values showed that outside was significantly drier than inside both shelters, especially if compared with the House of Hippolytus $\left(U=1316.5, p\right.$-value $=1.784 \mathrm{e}^{-10}$ for 2018 , and $U=208$, $\mathrm{p}$-value $<2.2 \mathrm{e}^{-16}$ for 2019). In addition, there were more variability on the $\mathrm{RH}$ data outside than inside the House of Hippolytus, which indicates that the shelter created a more stable environment in this respect. In the case of the House of the Griffins, this was only true for 2018, as there was no significant difference in relation to outside in 2019 $(U=3605$, $p$-value $=0.14)$. If both shelters are compared, the House of the Griffins had higher RH fluctuations ( $U=$ $1149.5, \mathrm{p}$-value $=1.08 \mathrm{e}^{-11}$ for 2018 , and $U=512.5$, $\mathrm{p}$-value $=2.2 \mathrm{e}^{-14}$ for 2019). Nevertheless, as Martínez-Garrido et al. (2016) sustain for the 2014-15 period, it seems for the range of $\mathrm{RH}$ variations that the shelter at the House of the Griffins also has a stabilising effect.

As expected for this type of climate, the $\mathrm{RH}$ outside drops during daytime because of the intense solar radiation. This effect is less pronounced inside the shelters although both followed the outside environment [figure 5]. Additionally, the maximum values were reached in May 2018 followed by September, so during those months there is a higher probability than $\mathrm{RH}$ crosses critical thresholds such as the $71 \%\left(\right.$ at $20^{\circ} \mathrm{C}$ ) for mirabilite hydration (Viles 2005), which is considered very damaging for stone monuments (Grossi and Esbert 1994).

Table 4.- Monthly means and standard deviations of daily RH values (\%) outside, and inside the shelters at the House of the Griffins and Hippolytus from May to September 2018 and 2019

\begin{tabular}{|l|c|c|c|c|c|c|}
\hline & \multicolumn{1}{|c|}{2018} & & & \\
\hline & $\begin{array}{c}\text { House of the } \\
\text { Griffins }\end{array}$ & Outside & $\begin{array}{c}\text { House of } \\
\text { Hippolytus }\end{array}$ & $\begin{array}{c}\text { House of the } \\
\text { Griffins }\end{array}$ & $\begin{array}{c}\text { Outside } \\
\text { House of } \\
\text { Hippolytus }\end{array}$ \\
\hline May & $63.34(14.85)$ & $66.40(21.46)$ & $64.56(14.26)$ & $39.55(11.12)$ & $37.34(10.57)$ & $39.94(9.97)$ \\
\hline June & $51.76(16.63)$ & $52.14(18.80)$ & $52.61(16.20)$ & $32.96(11.14)$ & $31.76(12.12)$ & $33.13(10.51)$ \\
\hline July & $36.17(11.10)$ & $36.31(11.80)$ & $36.94(10.93)$ & $31.67(9.99)$ & $29.98(9.79)$ & $32.52(9.20)$ \\
\hline August & $36.42(11.62)$ & $35.63(12.84)$ & $37.66(11.84)$ & $36.66(14.62)$ & $35.38(14.10)$ & $38.09(13.95)$ \\
\hline September & $49.27(11.62)$ & $46.65(16.69)$ & $51.09(12.05)$ & $42.72(9.83)$ & $38.24(9.57)$ & $44.16(9.16)$ \\
\hline
\end{tabular}




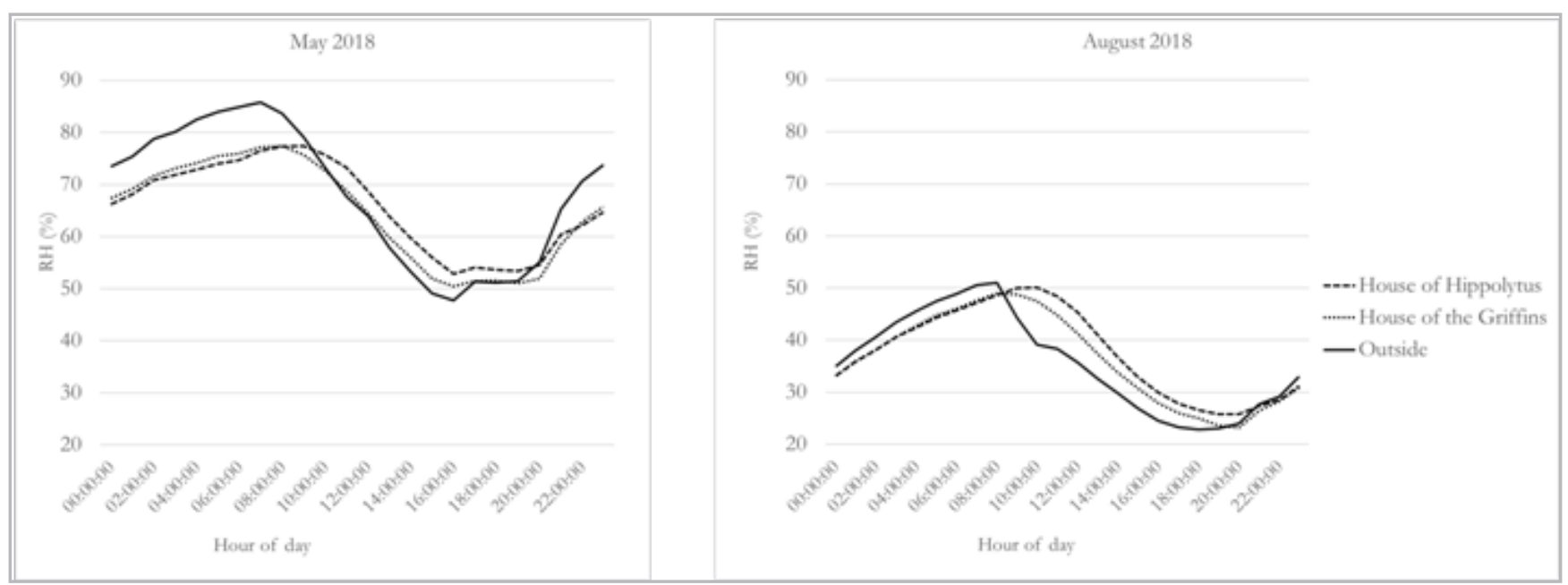

Figure 5.- :Hourly means of RH outside, and inside the shelters at the House of the Griffins and Hippolytus in May and August 2018, which corresponds to the wettest and driest months of the monitoring programme

\section{Discussion}

The data from May to September in 2018 and 2019 indicate that outside temperatures represent the most extreme values during days and nights, and shelters were found to have lower maximum temperatures and higher minimum ones in comparison to the outer environment. In addition, these conditions imply a contrasted thermal regime based on large temperature swings between day and night. However, the differences between maximum and minimum temperatures inside the sheltered areas were lower than outside, although relatively high in the House of the Griffins. Nevertheless, a diurnal temperature variance of around $12^{\circ} \mathrm{C}$ is probably negligible for thermal stress if compared with other studies on stone heritage (Al-Omari et al. 2014). Even if surface temperatures are considered equivalent to air temperatures with an approximate increase in $20^{\circ} \mathrm{C}$ (Bonazza et al. 2009), isolation weathering has only been found relevant for thermal cycles over $40-50^{\circ} \mathrm{C}$ (Lazzarini and Tabasso 1986; Viles 2005; Brimblecombe 2014) and this threshold is far from the mean temperature variations found at any of the positions in Complutum.

The climatic conditions of the area, characterised by a low precipitation rate, contribute to the dry environment found both outside and inside the shelters. A low RH (below 65\% as a generally ac-cepted limit) is beneficial for the conservation of the remains as it avoids biocolonization by many species of fungi, moss or algae (Caneva et al. 1991). The environment inside the House of Hippolytus was slightly more humid, as previously showed by Cabello Briones and Barrio Martín (2019), but still below that limit in average.

High temperatures and dry environments favour physical deterioration, specially salt weathering, which is more intense in locations with wide diurnal temperature and $\mathrm{RH}$ variations (Gutiérrez Elorza 2005). In this sense, the impact of decay is reduced inside the shelters. However, the regular restoration and maintenance of the site makes it difficult to determine the exact decay mechanism in sheltered areas. The environmental data points to different patterns if compared with exposed conditions. Shorter drying periods outside due to higher temperatures and wide $\mathrm{RH}$ ranges could lead to salt efflorescences on the surface while salts may accumulate inside the shelters due to slower evaporation time (Dohene and Price 2010). Although a drier environment means that it is unlikely that critical salt crystallisation thresholds are reached, a further study in this matter, taking into account specific salt mixtures, is recommended.

Therefore, the results show that the environmental conditions inside both shelters mirrored the daily cycles recorded outside but the covers were able to minimise the temperature effects on the ruins reducing the peaks and subsequently the daily range. This has been additionally seen in the study of the House of the Griffins undertaken by Martínez Garrido et al. (2016). The explanation may well be that shelters act as a barrier blocking the solar radiation and therefore reducing heating on the remains. This is a benefit also seen in other cases (Cabello Briones, 2016) and represent a key element for warm climates with intense sun and low humidity, making this preventive conservation solution highly suitable for Mediterranean countries.

The two types of shelters built in Complutum represent different approaches towards the conservation of the Roman archaeological site. The cover at House of the Griffins is a partially open shelter while at the House of Hippolytus can be described as a partially enclosed one. If both shelters are compared, the conditions inside the House of the Griffins followed more closely the outer conditions. The more open structure and the insufficient roof insolation of this shelter could be the reason. However, the higher mean temperatures and the diurnal temperature ranges are not enough to consider an imminent damage for the remains. However, isolated temperature peaks from sunlight 
coming through the sides, as it happened at certain times of the day at the House of the Griffins, support the idea that an open shelter without proper lateral cladding may be a less effective solution for this climate. The deficiencies of this shelter can be related to the fact that it was originally designed as provisional.

\section{Conclusion}

The results indicate that outside the shelters there were higher temperatures, more frequent tem-perature and $\mathrm{RH}$ fluctuations, and greater diurnal temperature ranges. These conditions are probably the responsible of the physical decay observed in the uncovered ruins and, therefore, the archaeological remains at Complutum would be in worst state of conservation if the shelters had not been built. Therefore, both shelters are avoiding further decay by keeping a more stable environment in relation to outside, although, in sight of the results, the cover at the House of Hippolytus would be the most suitable design.

Warm and dry areas are present in around $40 \%$ of the Spanish territory (Agencia Estatal de Meteorología 2011) and other Mediterranean countries with extremely valuable archaeological heritage such as Italy and Tunisia. A partially enclosed shelter with appropriate roof insolation and without restriction of air circulation could be the key for improving shelters in those locations as long as it is able to reduce temperature and $\mathrm{RH}$ fluctuations and avoid temperature extremes.

\section{Acknowledgment}

The author would like to thank Dr. Joaquín Barrio, Director of the Service for Conservation, Restoration and Scientific Studies of Archaeological Heritage (SECYR-UAM) for his support, and Dr. Sebastián Rascón, Municipal Archaeologist of Alcala de Henares and manager of Complutum for allowing the study at the Roman archaeological site.

\section{References}

ARGEA CONSULTORES. (2017). Servicio de mantenimiento arqueológico y restauración preventiva del conjunto monu-mental de la ciudad romana de Complutum y otros espacios arqueológicos de Alcalá de Henares. Project report. Alcalá de Henares: Servicio Municipal de Arqueología.

AGENCIA ESTATAL DE METEOROLOGÍA. (2011). Atlas climático ibérico: temperatura del aire y precipitación (1971-2000), Madrid: Instituto Nacional de Meteorología.

AL-OMARI, A., BRUNETAUD, X., BECK, K., AL-MUKHTAR, M. (2014). "Effect of thermal stress, condensation and freezing-thawing action on the degradation of stones on the Castle of Chambord, France", Environmental Earth Sciences, 71: 3977-3989. https://doi. org/10.1007/s12665-013-2782-4
ASLAN, Z. (1997). "Protective Structures for the Conservation and Presentation of Archaeological Sites", Journal of Conservation and Museum Studies, 3: 16-20.

BARRIO MARTíN, J. (2012). "Nuevos enfoques y criterios de restauración y conservación del Patrimonio Arqueológico". In Ensayos en torno al patrimonio cultural y al desarrollo sostenible en Chile y España, Blánquez, J. et al. (coords.). Madrid: Universidad Autónoma, 437-454.

BONAZZA, A., SABBIONI, C., MESSINA, P., GUARALDI, C., DE NUNTIIS, P. (2009). "Climate change im-pact: Mapping thermal stress on Carrara marble in Europe", Science of the Total Environment, 407: 4506-4512. https://doi.org/10.1016/j.scitotenv.2009.04.008

BRIMBLECOMBE P. (2014). “Environment and Architectural Stone". In Stone in Architecture, Siegesmund, S. and Snethlage, R. (eds.). Berlin: Springer, 317-347. https://doi.org/10.1007/978-3-642-45155-3 5

CABELLO-BRIONES, C. (2016). The Effects of Open Shelters on the Preservation of Limestone Remains at Archaeological Sites, Doctoral Thesis, University of Oxford.

CABELLO-BRIONES, C. (2017). "How to evaluate shelters for archaeological sites: some recommendations based on the use of exposure trial", Ge-conservación, 11:34-41. https://doi.org/10.37558/ gec.v11i0.442

CABELLO-BRIONES, C., VILES, H.A. (2017). "Deterioration at Archaeological Sites in Different Climatic Locations", International Journal of Architectural Heritage:Conservation, Analysis, and Restoration, 11-6: 816-828. https://doi.org/10.1080/15583058.2017.1300710

CABELLO- BRIONES, C. (2018). "Descubrir para cubrir: ¿Son las cubiertas sobre yacimientos arqueológicos realmente beneficiosas?". In ¿Y después? Control y mantenimiento del Patrimonio Cultural, una opción sostenible; Proceedings of the 6th GEIIC Congress (Vitoria, 20-22 September 2018). Vitoria: Grupo Español del IIC, 386-390.

CABELLO-BRIONES, C., BARRIO MARTíN, J. (2019). "Two shelters under review: Preliminary results from the Roman archaeological site of Complutum". In International Conference of IV International Congress Science and Technology for the Conservation of Cultural Heritage (Seville, 26-30 March 2019). Leiden: Balkema/CRC Press. https://doi.org/10.1201/9780429345470-43

CAMUFFO,D. (2019).MicroclimateforCultural Heritage:Measurement, Risk Assessment, Conservation, Restoration, and Maintenance of Indoor and Outdoor Monuments. Amsterdam: Elsevier. https://doi. org/10.1016/C2017-0-02191-2

CANEVA, G., NUGARI, M.P., SALVADORI, O. (1991). Biology in the Conservation of Works of Art. Rome: ICCROM.

CURTEIS, T. (2018). "The use of environmental survey and monitoring in the design and evaluation of archaeological shelters". In Protective shelters for archaeological sites; Proceedings of SYMPOSIUM (Herculaneum, 23-27 September 2013). Rome: The British School: 40-50. 
DE CASTRO, M.J., MARTÍN-VIDE, M., BRUNET, M. (2005). The climate of Spain: Past, present and scenarios for the 21st century. Madrid: Publicaciones Ministerio de Medio Ambiente.

DEMAS, M. (2013). "Protective Shelters for Archaeological Sites”. In Mosaics In Situ. An Overview of Literature on Conservation of Mosaics In Situ, Roby, T. and Demas, M. (eds.). Los Angeles: The Getty Conservation Institute.

DOEHNE, E., PRICE, C. A. (2010). Stone Conservation: An Overview of Current Research, Los Angeles: The Getty Conservation Institute.

GROSSI, C.M., ESBERT, R. M. (1994).“'Las sales solubles en el deterioro de rocas monumentales. Revisión bibliográfica", Materiales de Construcción 44 (235): 15-30.

GUTIÉRREZ ELORZA, M. (2005). “Weathering processes and resulting forms". In Climatic Geomorphology. Amsterdam: Elsvier, Chapter 11, 241-258.

MARTíNEZ-GARRIDO, M.I., ERGENÇ, D., FORT, R. (2016): “Wireless monitoring to evaluate the effectiveness of roofing systems over archaeological sites", Sensors and Actuators A, 252: 120-133. https:// doi.org/10.1016/j.sna.2016.10.038

LAZZARINI, L., TABASSO LAURENZI, M. (1986). Il restauro della pietra, Padova: Cedam.

PESARESI, P., STEWART, J. (2018). "Shelters evaluation, monitoring and maintenance in the context of archaeological site management". In Protective shelters for archaeological sites; Proceedings of SYMPOSIUM (Herculaneum, 23-27 September 2013). Rome: The British School: 58-82.

ROBY, T. (2006). "The Conservation of Mosaics in Situ: Preserving Context and Integrity". In Stories in Stone. Conserving Mosaics of Roman Africa. Masterpieces from the National Museums of Tunisia, Abed, A. B. (ed.). Los Angeles: The Getty Conservation Institute: 101-114.

RODRÍGUEZ FRADE, J. P., MADARIAGA MÉNDEZ, A., RASCÓN MARQUÉS, S. (2001). "Cubierta para las ruinas arqueológicas de la Casa de Hippolytus Complutum" [Online], In Memoria para el Premio Calidad a la Estética, Dirección General de Arquitectura y Vivienda de la Comunidad de Madrid. http://www.madrid.org/bdccm/premios/ PDF/LIBRO2001-2000/T3.pdf (Accessed November 2018).

SÁNCHEZ MONTES, A.L., RASCÓN MARQUÉS, S. (2012). "Musealización del proceso de excavación de la Casa de los Grifos (Alcalá de Henares, Madrid). La Casa de los Grifos en el contexto de los yacimientos musealizados en España". In VIII Jornadas de Patrimonio Arqueológico en la Comunidad de Madrid, (15-16 November 2011). Madrid: Comunidad de Madrid.

TORRACA, G. (2009). Lectures on Materials Science for Architectural Conservation. Los Angeles: The Getty Con-servation Institute.

VILES, H.A. (2005). "Microclimate and weathering in the central Namib Desert, Namibia", Geomorphology, 67-2: 189-209.

\section{Author/s}

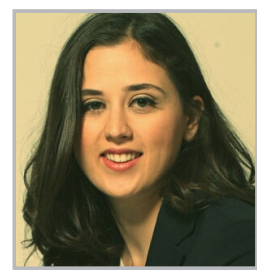

\section{Cristina Cabello Briones}

cristina.cabello@uam.es

Servicio de Conservación, Restauración y Estudios Científicos del Patrimonio Arqueológico, Universidad Autónoma de Madrid, Spain

Cristina Cabello Briones holds a PhD in Geography and the Environment from the University of Oxford. Her thesis is on the effects of open shelters on the preservation of limestone remains at archaeological sites. She also has an MA in Preventive Conservation from the University of Northumbria at Newcastle, a BA in Heritage Conservation from Escuela Superior de Conservación y Restauración de Bienes Culturales de Madrid, and a BA in Art History from Universidad Autónoma de Madrid.

https://doi.org/10.37558/gec.v17i1.756 